\title{
Composting of chicken manure with a mixture of sawdust and wood shavings under forced aeration in a closed reactor system
}

\author{
Waqas Qasim ${ }^{1} \cdot$ Min Ho Lee ${ }^{1} \cdot$ Byeong Eun Moon $^{1} \cdot$ Frank Gyan Okyere $^{1} \cdot$ Fawad Khan $^{1} \cdot$ Mohammad Nafees $^{2}$. \\ Hyeon Tae Kim ${ }^{1}$
}

Received: 5 November 2017 / Accepted: 26 July 2018 / Published online: 3 August 2018

(c) The Author(s) 2018

\begin{abstract}
Purpose This study aimed to achieve successful composting and aeration rate and to optimize the carbon:nitrogen (C:N) ratio to provide favourable conditions for the process. In the current experiment, investigation were made on variations in physico-chemical properties, i.e., temperature, ammonia and carbon dioxide emissions, pH, electrical conductivity (EC), organic matter (OM) and seed germination index (GI\%) of composting chicken manure mixed with sawdust and wood shavings under different aeration rates in a closed reactor system.

Methods Three cylindrical reactors (total volume, $60 \mathrm{~L}$ ) were used with three aeration rates of $0.25,0.50$ and $^{\circ} .75 \mathrm{~L} \mathrm{~min}^{-1}$ $\mathrm{kg}^{-1} \mathrm{OM}$. The air was dispensed from the bottom of an air compressor. The ambient and compost temperature were monitored thrice daily over 30 days of composting.

Results The highest temperatures were $56.9,55.8$ and $48.1{ }^{\circ} \mathrm{C}$, with $0.25,0.50$ and $0.75 \mathrm{~L} \mathrm{~min}^{-1} \mathrm{~kg}^{-1} \mathrm{OM}$ aeration rates, respectively. At the end of composting, lowest ammonia and carbon dioxide emissions were observed with $0.25 \mathrm{~L}$ min ${ }^{-1}$ $\mathrm{kg}^{-1} \mathrm{OM}$ aeration, indicating that this compost was more stable than other composts. The lowest GI was recorded on day 30 with $0.75 \mathrm{~L} \mathrm{~min}^{-1} \mathrm{~kg}^{-1} \mathrm{OM}$ aeration, indicating severe phytotoxicity in the substrate. Maximum OM degradation occurred with $0.25 \mathrm{~L} \mathrm{~min}^{-1} \mathrm{~kg}^{-1} \mathrm{OM}$ aeration.
\end{abstract}

Conclusion This study, therefore, suggested that $0.25 \mathrm{~L} \mathrm{~min}^{-1} \mathrm{~kg}^{-1} \mathrm{OM}$ aeration in the composing of the chicken manure mixed with sawdust and wood shavings in closed a reactor system provided the most favourable conditions for maturation.

Keywords Aeration $\cdot$ Chicken manure $\cdot$ Sawdust $\cdot$ Seed germination $\cdot$ Temperature $\cdot$ Wood shavings

Hyeon Tae Kim

bioani@gnu.ac.kr

Waqas Qasim

waqasdocuments2012@gmail.com

Min Ho Lee

kklmh89@naver.com

Byeong Eun Moon

be25moon@naver.com

Frank Gyan Okyere

okyerefrank200@yahoo.com

Fawad Khan

fawad.pid@gmail.com

Mohammad Nafees

nafees36@yahoo.com

1 Department of Bio-systems Engineering, Gyeongsang National University (Institute of Agriculture and Life Science), Jinju 52828, Korea

2 Department of Environmental Science, University of Peshawar, Peshawar, Khyber Pakhtunkhwa, Pakistan

\section{Introduction}

Composting manure is an effective approach to solve the problem of solid waste disposal (Hoitink 2000), and this method improves the manure management characteristics by decreasing its volume and weight and killing pathogens and stabilising the nutrients and organic matter (OM) within it (Michel et al. 1996; Tiquia et al. 1996, 2000). The application of compost to agricultural land is considered to be an economical, practical and environmentally beneficial management option (Brochier et al. 2012). Proper composting effectively reduces odour emission and nitrogen loss and makes the organic waste a relatively stable product that can be used as a fertilizer.

Poultry manure is rich in nutrients; therefore, it is beneficial for crop production and also improves the structural stability of the soil (Duong 2003). To correctly balance the compost to provide better conditions for microbes to fasten 
the decaying process, the carbon:nitrogen $(\mathrm{C}: \mathrm{N})$ ratio must be taken into account. Further, the successful composting of animal manures, which are usually rich in nitrogen (ZmoraNahum et al. 2007), with materials having a high carbon content, such as sawdust (Zhang and He 2006) and wood chips (Adhikari et al. 2008), has been reported. Lignocellulosic agricultural and forestry by-products such as pine shavings and sawdust are commonly used as bulking agents in composting with animal manures (Bernal et al. 2009). These products are common and easily available from woodworking companies in South Korea. An appropriate combination of waste materials is important for attaining high temperatures as it yields a suitable combination of carbon and nitrogen for the growth and activity of the microbial population (Singh and Kalamdhad 2012).

Composting requires oxygen for aerobic activity, although too much aeration can lead to excessive cooling, which inhibits the thermophilic condition required for optimum decomposition. However, too little aeration can lead to anaerobic conditions. The optimum aeration rate provides sufficient oxygen for aerobic decomposition. The aeration flow rate affects microbial activity, degradation rate and temperature during the composting process (Kuter et al. 1985). For successful composting, factors such as moisture content, $\mathrm{C}: \mathrm{N}$ ratio, aeration rate, temperature, $\mathrm{pH}$, composting materials and the method used should be appropriately controlled. Temperature, moisture content and other factors, such as $\mathrm{C} / \mathrm{N}$ ratio (nutrient balance), $\mathrm{pH}$ and available nutrients, have been previously shown to significantly impact composting performance (Jackson and Line 1997).

Different aeration rates have been recommended, such as $0.25 \mathrm{~L} \mathrm{~min}{ }^{-1} \mathrm{~kg}^{-1} \mathrm{OM}$ in the compost mixture of dairy manure and rice straw ( $\mathrm{Li}$ et al. 2008), $0.62 \mathrm{~L} \mathrm{~min}^{-1} \mathrm{~kg}^{-1}$ Volatile Solids in the composting of vegetable and fruit wastes (Arslan et al. 2011) and $0.5 \mathrm{~L} \mathrm{~min}^{-1} \mathrm{~kg}^{-1} \mathrm{OM}$ in the composting of chicken manure and sawdust (Gao et al. 2010). The aeration rates differed depending on the different materials being composted and the method of composting process. The objective of this work was to investigate the variations in physico-chemical properties, i.e., temperature, ammonia and carbon dioxide emissions, $\mathrm{pH}$, electrical conductivity (EC), OM and the seed germination index (GI) of composting chicken manure mixed with sawdust and wood shavings under different aeration rates in a closed reactor system.

\section{Materials and methods}

\section{Experimental setup}

Three cylindrical reactors with a total volume of $60 \mathrm{~L}$ (height, $0.66 \mathrm{~m}$; diameter, $0.34 \mathrm{~m}$ ) were used in this experiment. The compost reactors were insulated with a cover of polyurethane foam of $2.54-\mathrm{cm}$ width. A vertical rotational axis with blades was used before obtaining the samples to ensure the whole mixing of the composting quantity. The reactors were fitted with a valve for dropping the leachate.

The airflow rates in three reactors were $0.25,0.50$ and $0.75 \mathrm{~L} \mathrm{~min}^{-1} \mathrm{~kg}^{-1} \mathrm{OM}$. The air was dispensed from the bottom of an air compressor (Air Land S45-40-4.5, Korea), and the airflow timing was intermittent with 45 min of aeration followed by $15 \mathrm{~min}$ without aeration, which was controlled by a timer and solenoid valve (AutoSigma HPW2120). An airflow meter (Valve Acrylic Flowmeter, Cole-Parmer, USA) and pressure regulators were used to control airflow rates as shown in Fig. 1. A plastic grid was installed $0.08 \mathrm{~m}$ above the bottom of the reactor to support the composting bed and to ensure uniform air distribution. The compost temperature was monitored thrice daily at $10 \mathrm{am}, 2 \mathrm{pm}$ and $6 \mathrm{pm}$ at the three different layers of the substrate (top, middle and bottom) using a digital thermometer (Testo 905-T1). The ambient temperature was also recorded daily.
Fig. 1 Schematic diagram of a reactor with experimental apparatus. 1, air compressor; 2 , solenoid valve; 3 , timer; 4 , gas-washing bottle (solution of $\mathrm{NaOH}) ; 5$, gas-washing bottle (distilled water); 6, airflow meter; 7 , reactor with insulation; 8 , perforated plate; 9 , temperature probe; 10 , ammonia sensor; 11, carbon dioxide sensor; 12 , leachate outlet

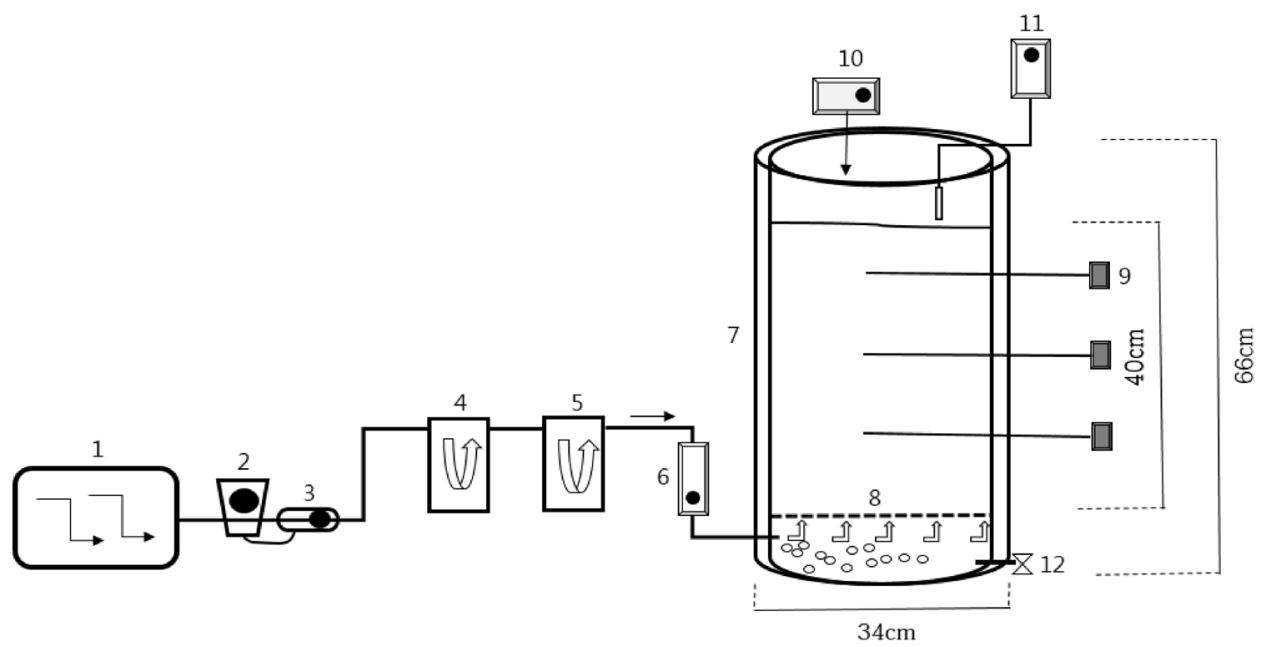


Table 1 Initial parameters of composting chicken manure mixed with sawdust and wood shaving

\begin{tabular}{lr}
\hline Parameters & \multicolumn{1}{c}{ Values } \\
\hline Moisture content, \%ww & $65 \pm 0.76$ \\
Organic matter, \%dw & $85.1 \pm 0.80$ \\
pH & $7.8 \pm 0.46$ \\
Electrical conductivity, $\mathrm{mS} \mathrm{cm}^{-1}$ & $2.12 \pm 0.05$ \\
C:N & $25 \pm 0.28$ \\
\hline
\end{tabular}

$C: N$ carbon:nitrogen, $d w$ dry weight, $w w$ wet weight

Before entering into the reactors, the air was mixed with a solution of sodium hydroxide to eliminate the traces of carbon dioxide. Then, air was moisturised by passing it through a gas-washing bottle containing $500 \mathrm{~mL}$ of distilled water before entering the reactor to maintain the humidity inside.

\section{Composting mixture}

Fresh poultry manure combined with sawdust and wood shavings were used as experimental materials. Poultry manure was collected from poultry farms, whereas sawdust and wood shavings were purchased from a wood-chipping mill. Sawdust and wood shavings were mixed (1:1) and the initial moisture content, organic matter content, $\mathrm{pH}, \mathrm{EC}$ and the $\mathrm{C} / \mathrm{N}$ ratio of the compost were determined. The manure with sawdust and wood shavings was mixed by means of a concrete mixer to achieve better homogenisation of the material. The initial moisture content and $\mathrm{C}: \mathrm{N}$ ratio were adjusted to approximately 65 and $25 \%$, respectively, for filling the three reactors (Table 1).

\section{Analytical methods}

Carbon dioxide emission was determined using Lutron MCH-383SD electrochemical sensor set above the composting material in each reactor. The emission rate was checked at 10-min intervals, and the recorded data were averaged for further analysis and interpretation (Qasim et al. 2017).

The ZDL-800 electrochemical sensor was set above the compost material in each reactor for the determination of ammonia. The exposure of an electrochemical sensor to high concentrations of ammonia over long periods leads to reading errors; therefore, the ZDL-800 sensor was checked at an interval of $1 \mathrm{~h}$ each day (Qasim et al. 2017).

The composting material was mixed by a vertical rotational axis with blades before samples were obtained. Approximately $50 \mathrm{~g}$ of the sample was taken from the top, middle and bottom layers of the substrate. The moisture content of the experimental material was analysed by oven drying at $105^{\circ} \mathrm{C}$ for $24 \mathrm{~h}$ (APHA 1995). The $\mathrm{C}$ and $\mathrm{N}$ content was determined by an automated LECO TruMac CNS elemental analyser. EC and $\mathrm{pH}$ were measured by mechanically shaking the samples with distilled water at a solid:water ratio of 1:10 (w/v) for $1 \mathrm{~h} . \mathrm{pH}$ and $\mathrm{EC}$ were measured using digital meters. The OM content (volatile solids) of the substance was calculated by heating in an oven at $550{ }^{\circ} \mathrm{C}$ for 6 h (APHA 1995).

\section{Phytotoxicity assay}

Aqueous extracts were used for testing seed germination and root length, which was performed by mechanical shaking the fresh samples for $1 \mathrm{~h}$ at a solid: double-distilled water ratio of 1:10 (w/v, dry weight). Approximately $5.0 \mathrm{~mL}$ of each sample extract was pipetted into a sterilised plastic Petri dish lined with a Whatman \#2 filter paper. Twelve radish seeds were equally placed on the filter paper and incubated in darkness at $25{ }^{\circ} \mathrm{C}$ for $72 \mathrm{~h}$. Each composting mixture sample was analysed in triplicates. The effects of treatments were assessed by counting the number of germinated seeds and determining root length. The responses were calculated by GI \% that was determined according to the following equation (Zucconi et al. 1981):

$$
\begin{aligned}
\mathrm{GI}(\%)= & \frac{\text { Seed germination }(\%)(\text { treatment }) \times \text { root length }(\text { treatment })}{\text { Seed germination }(\%)(\text { control }) \times \text { root length }(\text { control })} \\
& \times 100 .
\end{aligned}
$$

\section{Statistical analysis}

Statistical analysis was performed using the Prism 5 GraphPad program. Data were presented as mean \pm standard error of mean and analysed by one-way analysis of variance, followed by Bonferroni's multiple-comparison test with a significance level of $P<0.05$.

\section{Results and discussion}

\section{Temperature profile}

The temperature profile can be used to classify the composting stages. Figure 2 shows the temperature profile of the compost with three different aeration rates and the ambient temperature that was maintained at around $25^{\circ} \mathrm{C}$. The compost temperature increased due to $\mathrm{OM}$ degradation by microorganisms in the compost mass. The highest temperature in each treatment was $56.9,55.8$ and $48.1{ }^{\circ} \mathrm{C}$ for $0.25,0.50$ and $0.75 \mathrm{~L} \mathrm{~min}^{-1} \mathrm{~kg}^{-1} \mathrm{OM}$, respectively. These values were recorded on the third day at the middle of the compost pile. The highest temperature lasted for a longer time with an aeration rate of $0.25 \mathrm{~L} \mathrm{~min}^{-1} \mathrm{~kg}^{-1} \mathrm{OM}$. At $0.25 \mathrm{~L} \mathrm{~min}^{-1} \mathrm{~kg}^{-1} \mathrm{OM}$, temperature was maintained above 


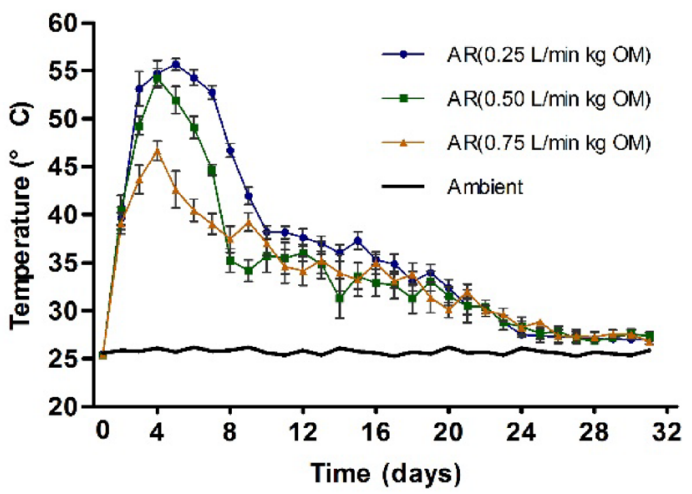

Fig. 2 Variations in temperature profiles during the composting process with three aeration rates

$55{ }^{\circ} \mathrm{C}$ for 3 days, which should be sufficient to kill pathogens. Stentiford (1996) reported that $55^{\circ} \mathrm{C}$ for 2 days was enough for maximum sanitation. Rising temperatures are associated with vigorous microbial activity and rapid organic matter degradation (Sarkar and Chourasia 2017). In the cylinder reactor with $0.75 \mathrm{~L} \mathrm{~min}^{-1} \mathrm{~kg}^{-1} \mathrm{OM}$ aeration rate, the temperature did not reach $50{ }^{\circ} \mathrm{C}$ throughout the experiment because of poor microbial activity and inadequate $\mathrm{OM}$ degradation. The high aeration rate adversely affected a rise in temperature. Lau et al. (1992) also reported that high aeration rates resulted in a cooling effect that was detrimental to the composting process. Nayak and Kalamdhad (2015) reported that decreased heat generation leads to temperature reduction in the composter. Temperature was significantly different in all the three treatments during the thermophilic phase $(P<0.05)$.

\section{Evaluation of $\mathrm{pH}$ and EC}

The evaluation of $\mathrm{pH}$ is shown in Fig. 3. During the thermophilic stage, $\mathrm{pH}$ increased significantly due to the decomposition of OM. At an aeration rate of $0.25 \mathrm{~L} \mathrm{~min}^{-1} \mathrm{~kg}^{-1}$

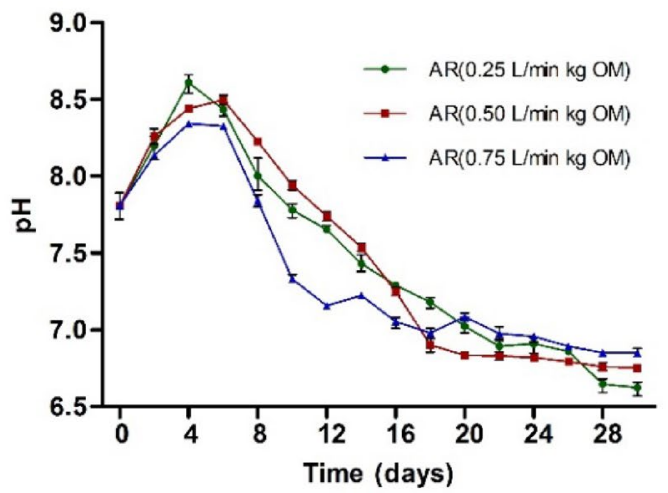

$\mathrm{OM}$, the $\mathrm{pH}$ of the compost increased from an initial $7.8-8.6$ on day 4 and then gradually decreased to 6.6 on day 30. At $0.50 \mathrm{~L} \mathrm{~min}^{-1} \mathrm{~kg}^{-1} \mathrm{OM}$, the $\mathrm{pH}$ of the compost increased from an initial 7.8-8.5 on day 6 and then gradually decreased to 6.8 on day 30 . At $0.75 \mathrm{~L} \mathrm{~min}^{-1} \mathrm{~kg}^{-1} \mathrm{OM}$, the $\mathrm{pH}$ of the compost increased from an initial 7.8-8.3 on day 4 and then gradually decreased to 6.9 on day 30 . The increase and decrease in $\mathrm{pH}$ are also directly related to the ammonia content in the compost, probably due to the decomposition of proteins into ammonium, as reported by other researchers (Liao et al. 1995; Raviv 2005).

EC levels indicate the salinity of the compost, and higher salt concentrations can be risky to the germination of seeds and plants when the compost is used for growing plants. Excessive salinity causes phytotoxicity, the level of which varies depending on the plant species (Aslam et al. 2008). The initial EC value was $2.2 \mathrm{mS} \mathrm{cm}{ }^{-1}$ in the reactors. EC values first increased to $4.8,4.14$ and 3.8 with aeration rates of $0.25,0.50$ and $0.75 \mathrm{~L} \mathrm{~min}^{-1} \mathrm{~kg}^{-1} \mathrm{OM}$, respectively, followed by a gradual decrease until the end of the composting process. The initial EC rise may be due to mineral salts such as phosphates and ammonium ions through the breakdown of compost materials (Gómez-Brandón et al. 2008) (Fig. 3).

\section{Evaluation of OM}

The rate of OM degradation is an indicator of the overall composting rate (Diaz and Savage 2007). In this experiment, the volume and mass of composting materials were considerably reduced. The evaluation of $\mathrm{OM}$ during the composting of chicken manure with a mixture of sawdust and wood shavings under different aeration rates is shown in Fig. 4. OM content decreased in all reactors, indicating the biodegradation of the compost. OM percentage of the compost decreased gradually from an initial $85 \%$ in all reactors to 61,64 and $65 \%$ with aeration rates of $0.25,0.50$ and $0.75 \mathrm{~L} \mathrm{~min}^{-1} \mathrm{~kg}^{-1} \mathrm{OM}$, respectively, on day 30 . The maximum $\mathrm{OM}$ degradation occurred with an aeration rate of

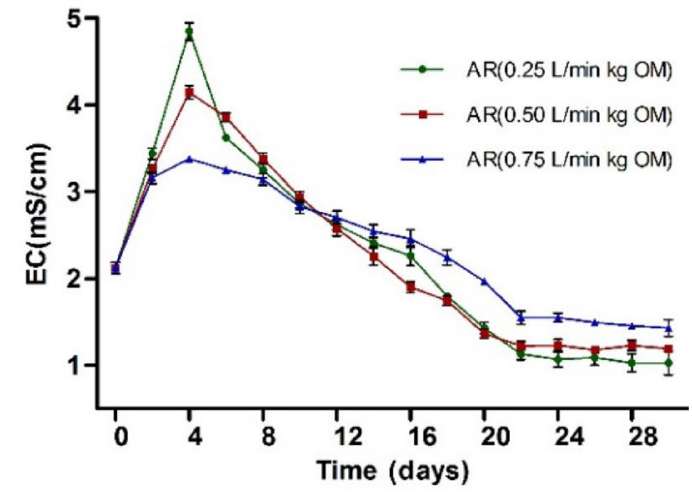

Fig. 3 Variations in $\mathrm{pH}$ and electrical conductivity (EC) during the composting process with three aeration rates 


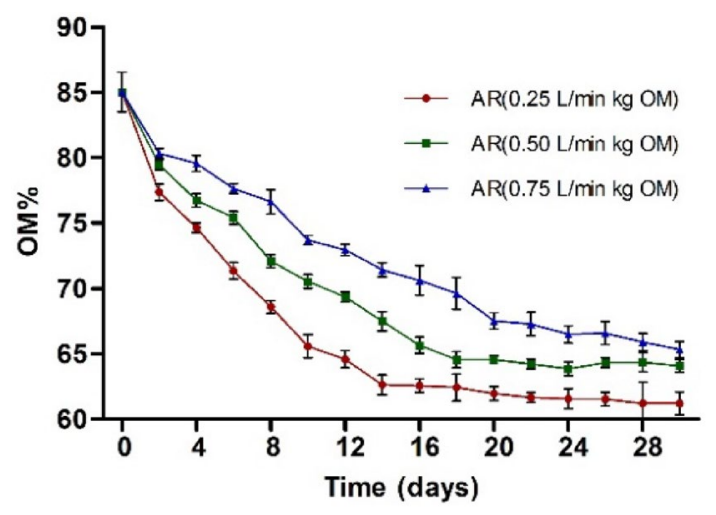

Fig. 4 Changes in Organic matter (OM) degradation (\%) during the composting process with three aeration rates

$0.25 \mathrm{~L} \mathrm{~min}^{-1} \mathrm{~kg}^{-1} \mathrm{OM}$, which provided an adequate oxygen supply for microorganisms. High rate of aeration adversely affected OM degradation during composting.

\section{Evaluation of ammonia and carbon dioxide}

The increase in ammonia emissions was observed in all reactors during the thermophilic stage, and these emissions then decreased in the maturation stage (Fig. 5a), although a higher ammonia emission of $333 \mathrm{ppm}$ was observed on day 2 with an aeration rate of $0.25 \mathrm{~L} \mathrm{~min}^{-1} \mathrm{~kg}^{-1} \mathrm{OM}$ due to high temperature and $\mathrm{pH}$. Ammonia emissions were exponentially correlated with temperature during the first stage of composting (Pagans et al. 2006). At day 30, no significant differences in ammonia emissions were noted between the reactors $(P<0.05)$. At the end of composting, the lowest ammonia emission of $34 \mathrm{ppm}$ was observed with an aeration rate of $0.25 \mathrm{~L} \mathrm{~min}^{-1} \mathrm{~kg}^{-1} \mathrm{OM}$, which also shows that the compost was more stable here than in the other reactors.

Figure $5 \mathrm{~b}$ shows the results of changes in carbon dioxide emission in all the three reactors. Carbon dioxide also directly followed the temperature profile. Compost stability has been evaluated by carbon dioxide; as the composting period increases, the microbial activity decreases. Petric et al. (2009) reported that the mass of carbon dioxide was directly proportional to microorganism activity during composting. The results here showed that the highest carbon dioxide emissions were observed between 2 and 4 days in all reactors. During the whole process, the highest variation was observed with an aeration rate of $0.75 \mathrm{~L} \mathrm{~min}^{-1} \mathrm{~kg}^{-1} \mathrm{OM}$, which shows that high aeration can lead to an unstable and immature compost. At day 30, there was a significant difference in ammonia emissions between the reactors $(P<0.05)$.

\section{Phytotoxicity assay}

GI shows the maturity and phytotoxicity of the compost (Guo et al. 2012). Figure 6 shows GI changes with aeration rates of $0.25,0.50$ and $0.75 \mathrm{~L} \mathrm{~min}^{-1} \mathrm{~kg}^{-1} \mathrm{OM}$ during the 30 days of composting. GI results in all reactors decreased in the early phase, which shows the relatively high salinity at the beginning. After 5 days, GI of all reactors started to increase gradually owing to the decomposition of toxic materials, which shows the maturation of

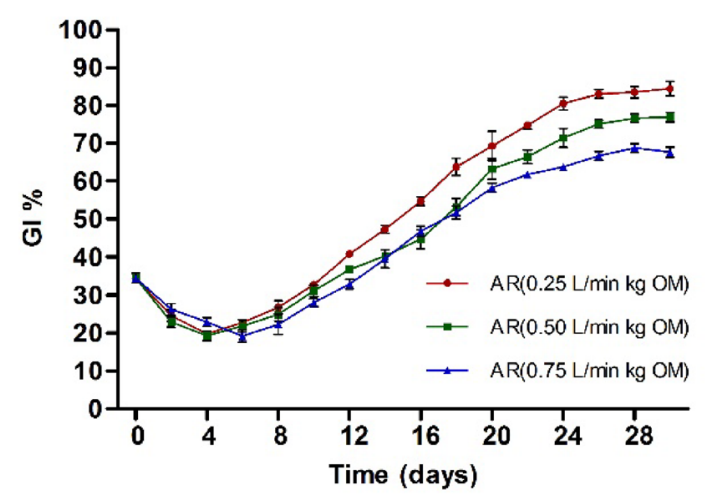

Fig. 6 Changes in the Germination index (GI\%) of compost with three different aeration rates
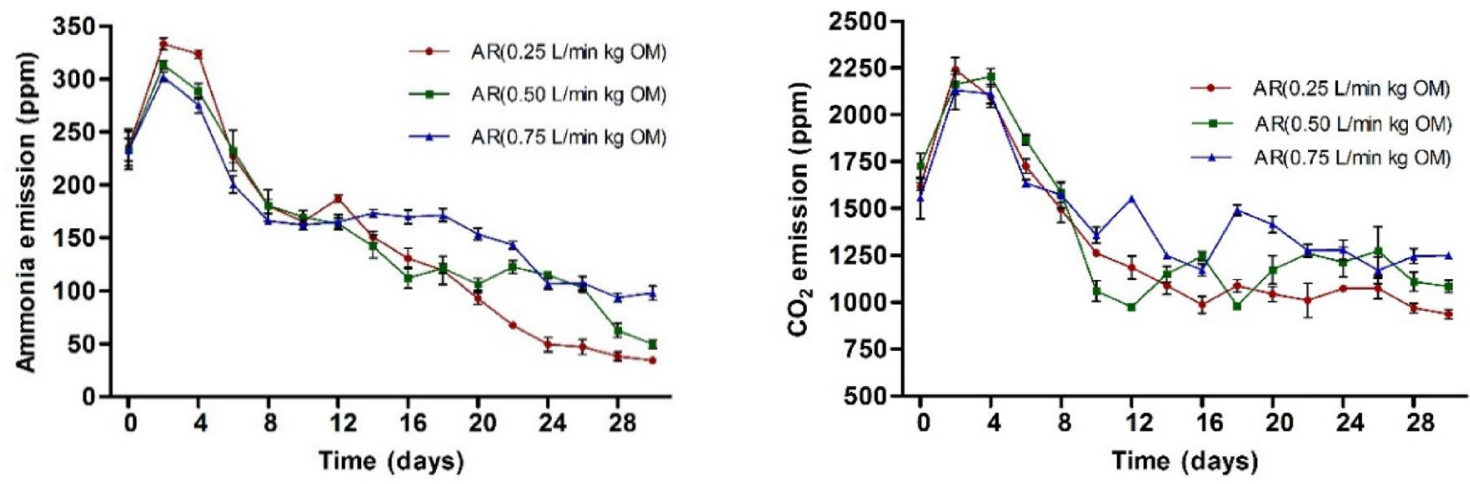

Fig. 5 Changes in ammonia and carbon dioxide emissions in the three reactors during composting 

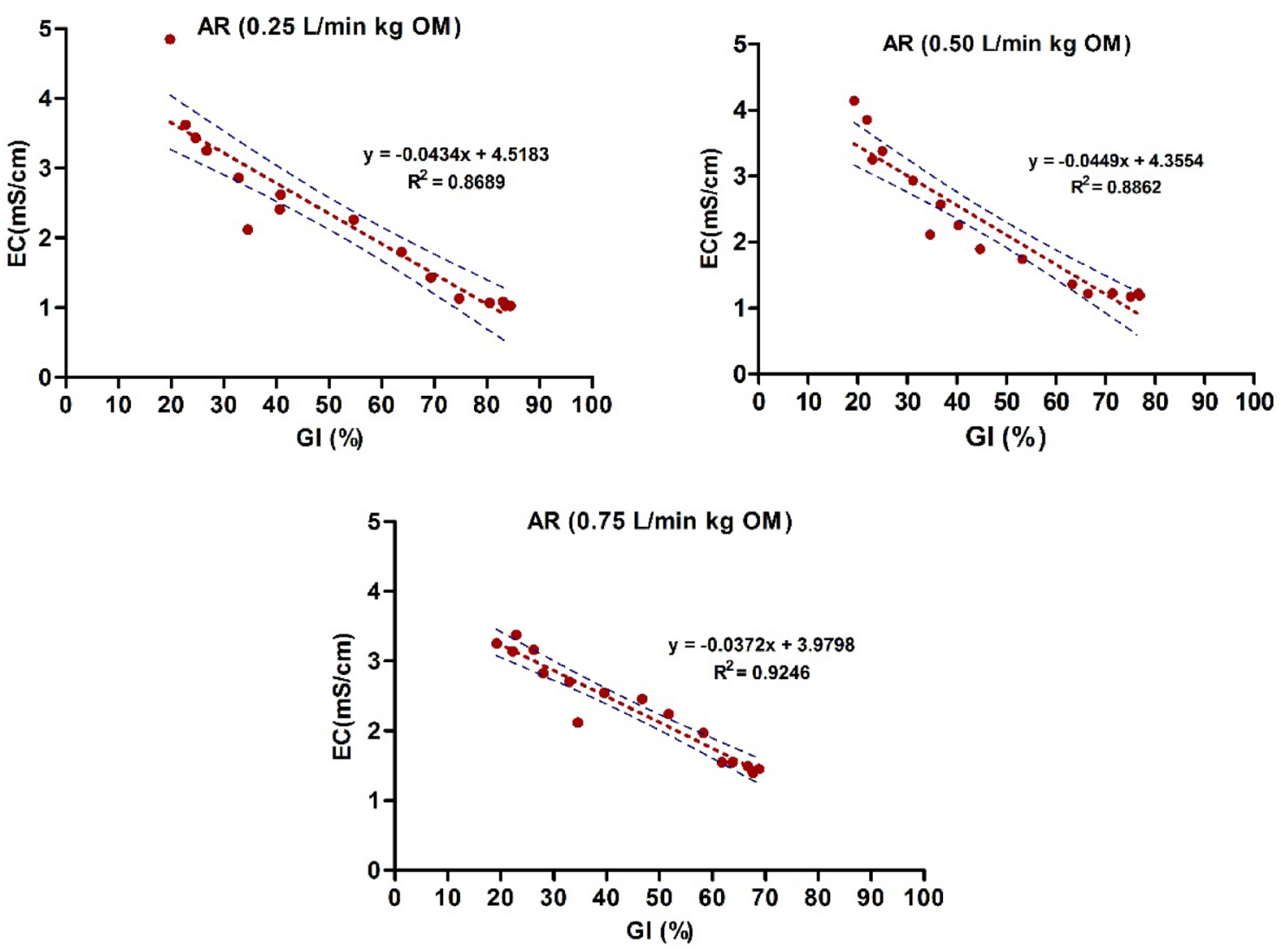

Fig. 7 Correlation between electrical conductivity (EC) and germination index (GI\%) of composting

the compost. The aeration rate had a significant influence on GI $(P<0.05)$. At the end of composting, GI was 84.5 , 76.9 and $67.7 \%$ with aeration rates of $0.25,0.50$ and 0.75 $\mathrm{L} \mathrm{min}^{-1} \mathrm{~kg}^{-1} \mathrm{OM}$, respectively. A GI of more than $80 \%$ indicates a phytotoxicity-free and mature compost (Guo et al. 2012). The lowest GI was with an aeration rate of $0.75 \mathrm{~L} \mathrm{~min}^{-1} \mathrm{~kg}^{-1} \mathrm{OM}$ at day 30 , indicating severe phytotoxicity in the substrate.

\section{Relationship between EC and GI}

A high salinity resulted in a decreased GI of seeds. EC shows the degree of salinity in composting, and it is a possible indicator of fertilizer phytotoxicity that will affect plant growth (Lin 2008). EC shows a significant negative correlation with GI of radish seeds (Fig. 7). The $R^{2}$ values were quite high in all reactors, i.e., $0.86,0.88$ and 0.92 with aeration rates of $0.25,0.50$ and $0.75 \mathrm{~L} \mathrm{~min}^{-1} \mathrm{~kg}^{-1}$ $\mathrm{OM}$, respectively. At the end of composting, GI had decreased to 84.5, 76.9 and $67.7 \%$ with EC values of 1.02 , 1.19 and 1.4 , respectively. This study suggested that low EC values of a compost provide a better condition for high seed germination.

\section{Conclusion}

The highest temperature of $56.9{ }^{\circ} \mathrm{C}$ was recorded on day 3 with an aeration rate of $0.25 \mathrm{~L} \mathrm{~min}^{-1} \mathrm{~kg}^{-1} \mathrm{OM}$, which also had the longest duration of high temperatures. Maximum $\mathrm{OM}$ degradation accrued with an aeration rate of $0.25 \mathrm{~L} \mathrm{~min}^{-1} \mathrm{~kg}^{-1} \mathrm{OM}$, which provided an adequate oxygen supply for microorganisms. At the end of composting, the lowest ammonia and carbon dioxide emissions were observed with an aeration rate of $0.25 \mathrm{~L} \mathrm{~min}^{-1} \mathrm{~kg}^{-1} \mathrm{OM}$, which also shows that the compost under this condition was more stable. With an aeration rate of $0.75 \mathrm{~L} \mathrm{~min}^{-1} \mathrm{~kg}^{-1} \mathrm{OM}$, the lowest GI was recorded on day 30 , indicating severe phytotoxicity in the substrate. The present study showed that the combination of sawdust and wood shavings with poultry manure in different aeration rates can be taken into account, which is also the main parameter of stabilizing the compost. Of the studied aeration rates, the rate of $0.25 \mathrm{~L} \mathrm{~min}^{-1} \mathrm{~kg}^{-1}$ $\mathrm{OM}$ provided the most favourable conditions for composting chicken manure with a mixture of sawdust and wood shavings in a closed reactor system.

Acknowledgements This research was supported by Korea Institute of Planning and Evaluation for technology in Food, Agriculture, Forestry 
and Fisheries (IPET) through Research Centre Support Program (Project No. 717001-7), Ministry of Agriculture, Food and Rural affairs (MAFRA).

Open Access This article is distributed under the terms of the Creative Commons Attribution 4.0 International License (http://creativeco mmons.org/licenses/by/4.0/), which permits unrestricted use, distribution, and reproduction in any medium, provided you give appropriate credit to the original author(s) and the source, provide a link to the Creative Commons license, and indicate if changes were made.

\section{References}

Adhikari BK, Barrington S, Martinez J, King S (2008) Characterization of food waste and bulking agents for composting. Waste Manag 28(5):795-804. https://doi.org/10.1016/j.wasman.2007.08.018

Arslan EI, Ünlü A, Topal M (2011) Determination of the effect of aeration rate on composting of vegetable-fruit wastes. Clean Soil Air Water 39:1014-1021. https://doi.org/10.1002/clen.201000537

Aslam DN, Horwath W, Vander G (2008) JS. Comparison of several maturity indicators for estimating phytotoxicity in compostamended soil. Waste Manag 28(11):2070-2076. https://doi. org/10.1016/j.wasman.2007.08.026

Bernal MP, Alburquerque JA, Moral R (2009) Composting of animal manures and chemical criteria for compost maturity assessment. A review. Bioresour Technol 100:5444-5453. https://doi. org/10.1016/j.biortech.2008.11.027

Brochier V, Gourland P, Kallassy M, Poitrenaud M, Houot S (2012) Occurrence of pathogens in soils and plants in a long-term field study regularly amended with different composts and manure. Agric Ecosyst Environ 160:91-98. https://doi.org/10.1016/j. agee.2011.05.021

Diaz LF, Savage GM (2007) Chapter 4 factors that affect the process. Waste Manag Ser 8:49-65. https://doi.org/10.1016/s1478 $-7482(07) 80007-8$

Duong TTT (2003) Compost effects on soil properties and plant growth. Doctoral dissertation

Gao M, Li B, Yu A, Liang F, Yang L, Sun Y (2010) The effect of aeration rate on forced-aeration composting of chicken manure and sawdust. Bioresour Technol 101(6):1899-1903. https://doi. org/10.1016/j.biortech.2009.10.027

Gómez-Brandón M, Lazcano C, Domínguez J (2008) The evaluation of stability and maturity during the composting of cattle manure. Chemosphere 70(3):436-444. https://doi.org/10.1016/j.chemo sphere.2007.06.065

Guo R, Li G, Jiang T et al (2012) Effect of aeration rate, C/N ratio and moisture content on the stability and maturity of compost. Bioresour Technol 112:171-178. https://doi.org/10.1016/j.biort ech.2012.02.099

Hoitink HAJ (2000) Trends in treatment and utilization of solid wastes through composting in the United States. Proc Int Compost Symp (ICS'99) 1(2):1-13

Jackson MJ, Line MA (1997) Windrow composting of a pulp and paper mill sludge: Process performance and assessment of product quality. Comp Sci Utili 5(3):6-14. https://doi.org/10.1080/10656 57X.1997.10701880

Kuter GA, Hoitink HAJ, Rossman LA (1985) Effects of aeration and temperature on composting of municipal sludge in a full-scale vessel system. J (Water Pollut Control Fed) 7:309-315

Lau AK, Lo KV, Liao PH, Yu JC (1992) Aeration experiments for swine waste composting. Bioresour Technol 41(2):145-152. https ://doi.org/10.1016/0960-8524(92)90185-Z
Li X, Zhang R, Pang Y (2008) Characteristics of dairy manure composting with rice straw. Bioresour Technol 99(2):359-367. https ://doi.org/10.1016/j.biortech.2006.12.009

Liao PH, May AC, Chieng ST (1995) Monitoring process efficiency of a full-scale invessel system for composting fisheries wastes. Bioresour Technol 54(2):159-163. https://doi.org/10.1016/09608524(95)00123-9

Lin C (2008) A negative-pressure aeration system for composting food wastes. Bioresour Technol 99(16):7651-7656. https://doi. org/10.1016/j.biortech.2008.01.078

Michel FC, Forney LJ, Huang AJF et al (1996) Effects of turning frequency, leaves to grass mix ratio and windrow vs. pile configuration on the composting of yard trimmings. Compost Sci Util 4(1):26-43. https://doi.org/10.1080/1065657x.1996.10701816

Nayak AK, Kalamdhad AS (2015) Sewage sludge composting in a rotary drum reactor: stability and kinetic analysis. Int J Recycl Org Waste Agric 4(4):249-259. https://doi.org/10.1007/s4009 3-015-0104-4

Pagans E, Barrena R, Font X, Sánchez A (2006) Ammonia emissions from the composting of different organic wastes. Dependency on process temperature. Chemosphere 62(9):1534-1542. https://doi. org/10.1016/j.chemosphere.2005.06.044

Petric I, Šestan A, Šestan I (2009) Influence of wheat straw addition on composting of poultry manure. Process Saf Environ Prot 87(3):206-212. https://doi.org/10.1016/j.psep.2009.02.002

Qasim W, Moon BE, Phonsuwan M, Jo JS, Lee MH, Nafees M, Kim HT (2017) Effects of an aluminum sulfate and ferric chloride blend on poultry litter characteristics in vitro. J Appl Poult Res. https://doi.org/10.3382/japr/pfx046

Raviv M (2005) Production of high-quality composts for horticultural purposes: a mini-review. HortTechnology 15:52-57

Sarkar P, Chourasia R (2017) Bioconversion of organic solid wastes into biofortified compost using a microbial consortium. Int $\mathrm{J}$ Recycl Org Waste Agric 6(4):321-334. https://doi.org/10.1007/ s40093-017-0180-8

Singh J, Kalamdhad AS (2012) Concentration and speciation of heavy metals during water hyacinth composting. Bioresour Technol 124:169-179. https://doi.org/10.1016/j.biortech.2012.08.043

Stentiford EI (1996) Composting control: principles and practice. Sci Compost. https://doi.org/10.1007/978-94-009-1569-5_6

Tiquia SM, Tam NFY, Hodgkiss IJ (1996) Microbial activities during composting of spent pig-manure sawdust litter at different moisture contents. Bioresour Technol 55(3):201-206. https://doi. org/10.1016/0960-8524(95)00195-6

Tiquia SM, Richard TL, Honeyman MS (2000) Effect of windrow turning and seasonal temperatures on composting of hog manure from hoop structures. Environ Technol (UK) 21(9):1037-1046. https:// doi.org/10.1080/09593332108618048

Zhang Y, He Y (2006) Co-composting solid swine manure with pine sawdust as organic substrate. Bioresour Technol 97(16):20242031. https://doi.org/10.1016/j.biortech.2005.10.004

Zmora-Nahum S, Hadar Y, Chen Y (2007) Physico-chemical properties of commercial composts varying in their source materials and country of origin. Soil Bio Biochem 39(6):1263-1276. https://doi. org/10.1016/j.soilbio.2006.12.017

Zucconi F, Pera A, Forte M, De Bertoldi M (1981) Evaluating toxicity of immature compost. Biocycle 22(2):54-57

Publisher's Note Springer Nature remains neutral with regard to jurisdictional claims in published maps and institutional affiliations. 